TAPROBANICA, ISSN 1800-427X. April, 2010. Vol. 02, No. 01: pp. 1-5.

(C) Taprobanica Nature Conservation Society, 146, Kendalanda, Homagama, Sri Lanka.

\title{
EDITORIAL
}

\section{Taxonomy in the century of extinctions: taxonomic gap, taxonomic impediment, taxonomic urgency}

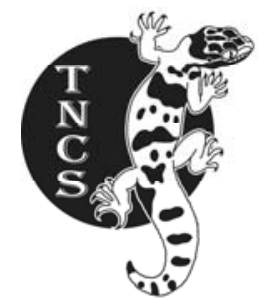

Our knowledge of the living species of the earth is still dramatically incomplete. Actually, few domains of scientific knowledge are in such an unsatisfying situation. Taxonomists have so far described less than 2 million species, whereas, using various methods, the total number of species was estimated to at least 7-8 million, but perhaps 10, 50, 100 million or even more (Groombridge, 1992; Heywood \& Watson, 1995; Reaka-Kudla et al., 1997). This huge taxonomic gap (Dubois, 2010a) is both quantitative and qualitative, as very little is known of most of the species that have been "described" and named so far (Dubois, 1998). If the work of increment of our database on specific diversity continued at the same pace as in the past, centuries would be necessary to complete our inventory of the planet’s species (González-Oreja, 2008). However, time is pressing, because of the biodiversity crisis (Wilson, 1985). The aggressions of the biosphere by our civilisation result in a drastic destruction and disappearance of natural ecosystems and, combined with other threats (physico-chemical and biotic pollution, over-exploitation by man, etc.), entail mass extinctions of species which will be irreversible. Many of the species that are currently disappearing with the forests, aquatic and other habitats that harboured them, will carry away forever with them not only molecules or other inventions of life that could have been useful to medicine, agronomy or other human needs, but also a plethora of irreplaceable information on biodiversity, evolution, adaptation and innovations, not to mention their aesthetic and cultural value. No serious hope exists to really stop or even significantly reduce the destructions on hand, as they are due both to human demographic growth and to the destructive kind of relations our current societies have with their environment, two factors that are not likely to change in the coming decades.

The taxonomic urgency (Dubois, 2010a), i.e., the imperious need of an acceleration of our taxonomic inventory of the planet (Wheeler et al., 2004), is currently far from having been identified by our governments, by the decision-makers in matters of scientific research and by most scientific institutions. Before it is too late, much more funding should be invested into taxonomic research, museum collections, training and hiring of professional taxonomists. The vanishing species of our planet are not in the computers and sequencers of our cities, but in the threatened natural habitats, and the main limiting factor for the increase of our knowledge on animal and plant species is field work devoted to their discovery, study and collection in the wild (May, 2004).

It is of utmost importance to consider the discovery, collection, storing in collections, study and description of specimens and tissues of the still unknown species of the biosphere, before they turn extinct, as an absolute priority for biology in our century of extinctions (Dubois, 2003). This is in fact much more urgent than clarifying their phylogenetic relationships or studying the modalities of their evolution, because evolution is not teleological: once they are extinct, all possible information about them will be lost and forever unavailable and no evolutionary theory or model, no "predictive taxonomy", will ever tell us what these vanished species looked like and what were their characters. Molecular data on cladistic relationships are certainly very useful and interesting to generate hypotheses on the relationships between the known taxa and on the evolutionary pathways that gave birth to them. However, and however complete and accurate they can be, they will never allow to predict the existence and the characters of taxa that have not yet been collected and studied.

The group of amphibians, that has long remained under-studied by zoologists, has prompted renewed and deeper interest in the last decades. Several new "extraordinary" discoveries were made in this group, which provide a new vision of the diversity, evolution, adaptations and "inventions" of these animals. Strikingly, most of these unexpected discoveries owe nothing to phylogenetic studies per se, although in some cases subsequent phylogenetic research has brought interesting additional data. In many cases, the core of the 
discovery was not molecular cladistic work, but field and laboratory work on the organisms themselves, not on their relationships. To support this quite unusual statement, let us just consider briefly some of these exciting novelties. Some do not belong in the field of taxonomy but simply in the study of "natural history", including behaviour, reproduction, etc. Field study alone allowed to establish that males of the "extraordinary" toad Bufo periglenes (also now extinct) did not produce mating call but used their bright coloration to meet females for breeding (Jacobson \& Vandenberg, 1991), unlike most other true toads: their DNA sequence could not have provided this information. Field studies resulted in the unexpected discovery that long-known species of ranid frogs breeding in torrents use ultra-sonic communication (Shen et al., 2008; Arch et al., 2009; Boeckle et al., 2009), although all other ranid species studied so far do not. Other findings involve genuine discovery of new species having unusual characteristics. The Australian frog Rheobatrachus silus was found through simple field exploration, which led to the subsequent discovery that this species and its sister-species Rheobatrachus vitellinus (now both extinct) were gastric-brooding, a unique phenomenon among vertebrates (Tyler, 1983). This was totally unpredictable, all the more that these two species were nested in a group of frogs with "normal" reproduction with free aquatic tadpoles. The Puerto Rican frog Eleutherodactylus jasperi, nested in a group of hundreds of species of frogs with direct development outside the female body, was found to be ovoviviparous only through study of its actual reproduction mode (Drewry \& Jones, 1976; Wake, 1978), which was unpredictable under any "model”. The finding of the genus Karsenia, a Korean representative of the salamander family Plethodontidae (Min et al., 2005), until then only known in North America and western Europe, was initially due to "simple field work", and the same applies to the frog genus Nasikabatrachus from southern India, with unexpected relationships with the frogs of the family Sooglossidae from Seychelles (Biju \& Bossuyt, 2003). Compared to other parts of the world, few new amphibian species have recently been discovered in Europe, a longstudied area with a relatively poor amphibian fauna. Some of them were due to use of modern research techniques such as bioacoustics or molecular approaches which showed that what had long been considered a single species was in fact a complex of species (Dubois, 1998). But a few of them were "brand new" discoveries of totally unknown species, even in this well-explored area, such as Alytes muletensis (Hemmer \& Alcover, 1984) and Rana pyrenaica (Serra-Cobo, 1993). No "theory of evolution", no model, no "law", could have allowed to imagine that the central Asian toad Bufo pseudoraddei baturae, against all treatises of genetics, is triploid and maintains pure triploid populations over the years through previously unknown gametogenetic pathways (Stöck et al., 2002) and, more generally, that in the well-known Eurasian Bufo viridis group, several distinct triploid and tetraploid taxa occur in central Asia (Stöck et al., 2006). The same applies to the European green frogs of the genus Pelophylax, many populations of which are composed of individuals with a peculiar gametogenesis and displaying "sexual parasitism" at each generation (Graf \& Polls Pelaz, 1989), or to the North American salamanders of the genus Ambystoma, whose populations include diploid to pentaploid hybrid individuals resulting from hybridizations between five species and with peculiar gametogeneses and in some cases gynogenesis (Bogart et al., 2007). These findings also question the relevance of the reductionist approach to the "species problem" through the hopeless quest for a "unified species concept".

Despite the many books that discussed the so-called "laws of evolution", the "inventiveness" of living organisms is unlimited and cannot be reduced to "laws": the only common feature to all natural situations and to all facts of "biological evolution" is that natural organisms and populations do change and evolve through time, but in which direction they did so can only be reconstructed afterwards, not predicted beforehand. Therefore, biologists really interested in living organisms, their characters and their evolution, more than on models and theories about them, cannot be indifferent to the process of mass extinctions which is currently taking place on earth: many species that have not yet been discovered in the field and studied are likely to disappear in the coming decades without having told us their "secrets".

Some scientists from other research domains have suggested that the field work for collecting and studying organisms could be entrusted to "parataxonomists", i.e. local people with a traditional knowledge of biodiversity in their native regions, therefore requiring lower salaries than professional researchers. This proposal is one among many examples of the contemptuous attitude of some scientists towards taxonomy. Nobody is proposing that research in astronomy, oceanography, physics, chemistry, physiology, neurology, ecology, etc., be carried out at a lower cost by "parascientists", amateurs, students or other nonprofessionals. Taxonomic field work and laboratory research is fully efficient only if carried out by 
competent professionals. We need specialised pre-doctoral and doctoral teaching in taxonomy, post-doctoral contracts and job positions for taxonomists (in museums, universities and other research institutions), proper funding for field work and for the permanent storage of specimens, tissues and information attached to them in specialised institutions (usually museums). However, the situation in this respect so far is highly preoccupying. Although identified more than 15 years ago (Anonymous, 1994), the taxonomic impediment, i.e., the lack of professional positions and appropriate funding, is still not properly addressed, and the solutions put forward by some, which rely mostly on computerisation of research and on molecular approaches, will not solve the problem (de Carvalho et al., 2005, 2007, 2008): more than "modern techniques", what taxonomy needs is working time in the field and laboratory, brains and arms, i.e., salaries, that is, the most difficult resource to obtain in our society in crisis (Dubois, 2010a).

An important brake to taxonomic research is exerted nowadays by the existence of more and more constraining laws regarding the collection of specimens in the field, their storing in museums and their transportation. These laws are usually justified by their promoters by concerns about the "conservation" of natural populations and species, if not by purely commercial reasons. Whereas they may be understood towards amateur collectors of specimens for purposes of hobby collection or trade, they are not justified when they impede professionals of taxonomic research to carry out the inventory of the biodiversity of a region or ecosystem. How could it be possible to "protect" what is still unknown? Solving these questions should not be left to the individual initiative of isolated researchers or research teams, but should be cared of at the highest levels, i.e., at States or other high administrative levels. However, this will be possible only when the irreplaceable role of taxonomy in the knowledge of the living species of the earth, which is indispensable for any proper "conservation" action, is understood.

In the meanwhile, i.e., until professional positions in taxonomy drastically increase, an important proportion of the work of taxonomic survey of our planet will continue to be carried out by amateurs, or by scientists from other research fields, doing taxonomy as a "side-activity" of their other works. Taxonomists should not show neglect or contempt for these works, as they bring a welcome support to the highly insufficient effort put by "official research" and by society as a whole on this work of inventory. But they should help amateur taxonomists to improve the quality of their work and to produce high-standard, long-lasting publications that will be reliable references for the future. Some advice may be useful to newcomers in this field, as well as to some already practising taxonomists who have missed an academic training in taxonomy. It was therefore felt useful to provide a few general guidelines in this respect, in a more technical paper that is a companion to this editorial (Dubois, 2010b).

\section{Literature Cited}

Anonymous [Systematics Agenda 2000], 1994. Charting the biosphere: a global initiative to discover, describe and classify the world's species. Technical report. NewYork, American Museum of Natural History, American Society of Plant Taxonomy, Society of Systematic Biologists and the Willi Hennig Society: 1-34.

Arch, V.S., T. U. Grafe, M. Gridi-Papp and P. M. Narins, 2009. Pure ultrasonic communication in an endemic Bornean frog. PLoS ONE, 4 (4): e5413. [doi:10.1371/journal.pone.0005413].

Biju, S. D. and F. Bossuyt, 2003. New frog family from India reveals an ancient biogeographical link with the Seychelles. Nature, 425: 711-714.

Boeckle, M., D. Preininger and W. Hödl, 2009. Communication in noisy environments. I. Acoustic signals of Staurois latopalmatus Boulenger, 1887. Herpetologica, 65 (2): 154-165.

Bogart, J. P., K. Bi, J. Fu, D. W. A. Noble and J. Niedzwiecki, 2007. Unisexual salamanders (genus Ambystoma) present a new reproductive mode for eucaryotes. Genome, 50: 119-136.

De Carvalho, M. R., F. A. Bockmann, D. S. Amorim and C. R. F. Brandão, 2008. Systematics must embrace comparative biology and evolution, not speed and automation. Evolutionary Biology, 35: 150-157. 


\section{EDITORIAL}

De Carvalho, M. R., F. A. Bockmann, D. S. Amorim, C. R. F. Brandão, M. de Vivo, J. L. de Figueiredo, H. A. Britski, M. C. C. de Pinna, N. A. Menezes, F. P. L. Marques, N. Papavero, E. M. Cancello, J. V. Crisci, J. D. McEachran, R. C. Schelly, J. G. Lundberg, A. C. Gill, R. Britz, Q. D. Wheeler, M. L. J. Stiassny, L. R. Parenti, L. M. Page, W. C. Wheeler, J. Faivovich, R. P. Vari, L. Grande, C. J. Humphries, R. DeSalle, M. C. Ebach and G. Nelson, 2007. Taxonomic impediment or impediment to taxonomy? A commentary on systematics and the cybertaxonomic-automation paradigm. Evolutionary Biology, 34: 140-143.

De Carvalho, M. R., F. A. Bockmann, D. S. Amorim, M. de Vivo, M. de Toledo-Piza, N. A. Menezes, J. L. de Figueiredo, R. M. C. Castro, A. C. Gill, J. D. McEachran, L. J. V. Compagno, R. C. Schelly, R. Britz, J. G. Lundberg, R. P. Vari and G. Nelson, 2005. Revisiting the taxonomic impediment. Science, 307: 353.

Drewry, G. E. and K. L. Jones, 1976. A new ovoviviparous frog, Eleutherodactylus jasperi (Amphibia, Anura, Leptodactylidae), from Puerto Rico. Journal of Herpetology, 10: 161-165.

Dubois, A., 1998. List of European species of amphibians and reptiles: will we soon be reaching "stability”? Amphibia-Reptilia, 19: 1-28.

Dubois, A., 2003. The relationships between taxonomy and conservation biology in the century of extinctions. Comptes rendus Biologies, 326 (suppl. 1): S9-S21.

Dubois, A., 2010a. Zoological nomenclature in the century of extinctions: priority vs. usage. Organisms Diversity \& Evolution, 10: 259-274.

Dubois, A., 2010b. Describing new species. Taprobanica, 2 (1): 6-24.

González-Oreja, J. A., 2008. The Encyclopedia of Life vs. The Brochure of Life: exploring the relationships between the extinction of species and the inventory of life on earth. Zootaxa, 1965: 61-68.

Graf, J.-D. and M. Polls Pelaz, 1989. Evolutionary genetics of the Rana esculenta complex. In: Dawley R. M. and J. P. Bogart (Eds.). Evolution and ecology of unisexual vertebrates, Albany, The New York State Museum: 289302.

Groombridge, B. (Ed.), 1992. Global biodiversity: status of the earth living ressources. London, Chapman \& Hall: $\mathrm{i}-\mathrm{xx}+1-585$.

Hemmer, H. and J. P. Alcover (Eds.), 1984. Història biològica del ferreret. Mallorca, Moll: 1-252.

Heywood, V. H. and R. T. Watson (Ed.) 1995. Global biodiversity assessment. Cambridge Cambridge University Press: i-xi+1-1140.

Jacobson, S. K. and J. J. Vandenberg, 1991. Reproductive ecology of the endangered golden toad (Bufo periglenes). Journal of Herpetology, 25 (3): 321-326.

May, R. M., 2004. Tomorrow’s taxonomy: collecting new species in the field will remain the rate-limiting step. Philosophical Transactions of the royal Society of London, (B), 359: 733-734.

Min, M. S., S. Y. Yang, R. M. Bonett, D. R. Vieites, R. A. Brandon and D. B. Wake, 2005. Discovery of the first Asian plethodontid salamander. Nature, 435: 87-90.

Reaka-Kudla, M. L., D. E. Wilson and E. O. Wilson (Eds.) 1997. Biodiversity II. Washington, Joseph Henry Press: i-vii+1-551.

Serra-Cobo, J., 1993. Descripción de una nueva especie europea de rana parda (Amphibia, Anura, Ranidae). Alytes, 11 (1): 1-15. 


\title{
EDITORIAL
}

Shen, J.-X., A. S. Feng, Z.-M. Xu, Z.-L. Yu, V. S. Arch and X.-J. Yu, 2008. Ultrasonic frogs show hyperacute phonotaxis to female courtship calls. Nature, 453 (7197): 914-916.

Stöck, M., D. K. Lamatsch, C. Steinlein, J. T. Epplen, W.-R. Grosse, R. Hock, T. Klapperstück, K. P. Lampert, U. Scheer, M. Schmid and M. Schartl, 2002. A bisexually reproducing all-triploid vertebrate. Nature Genetics, 30 (3): 325-328.

Stöck, M., C. Moritz, M. Hickerson, D. Frynta, T. Dujsebayeva, V. Eremchenko, R. Macey, T. J. Papenfuss and D. B. Wake, 2006. Evolution of mitochondrial relationships and biogeography of Palearctic green toads (Bufo viridis subgroup) with insights in their genomic plasticity. Molecular Phylogenetics \& Evolution, 41: 663-689.

Tyler, M. J. (Ed.), 1983. The gastric brooding frog. London \& Canberra, Croom Helm: i-x+1-163.

Wake, M. H., 1978. The reproductive biology of Eleutherodactylus jasperi (Amphibia, Anura, Leptodactylidae), with comments on the evolution of live-bearing systems. Journal of Herpetology, 12: 121-133.

Wheeler Q. D., P. H. Raven and E. O. Wilson, 2004. Taxonomy: impediment or expedient?. Science, 303: 285.

Wilson, E. O., 1985. The global biodiversity crisis: a challenge to science. Issues in Science \& Technology, 2: 2029.

\author{
Alain Dubois \\ Sectional Editor: Taprobanica, the journal of Asian Biodiversity \\ December $18^{\text {th }}, 2010$ \\ Vertébrés: Reptiles \& Amphibiens \\ UMR 7205 Origine, Structure \& Evolution de la Biodiversité \\ Département Systématique \& Evolution \\ Muséum national d'Histoire naturelle \\ CP 30, 25 rue Cuvier, 75005 Paris \\ FRANCE
}

